\title{
PERLINDUNGAN HAK PEKERJA ASKES PASCA PEMBUBARAN PT ASKES (PERSERO)*
}

\author{
Ronald H. Sianturi, ${ }^{* *}$ Theresia Simatupang, ${ }^{* * *}$ Rahmayanti, ${ }^{* * * *}$ and Satria B. Hariandja ${ }^{* * * * *}$ \\ Departemen Hukum Perburuhan Fakultas Hukum Universitas Prima Indonesia, Medan \\ Jalan Sekip Simpang Sikambing, Medan, Sumatera Utara 20113
}

\begin{abstract}
This article discusses about the Askes Workers rights protection after 'dissolution without liquidation of PT. Askes (Persero), which The Askes Workers turned to BPJS Kesehatan workers. This research is yuridis normative by using secondary data. The results showed that the workers'rights protection after dissolution based on Law No.13 of 2003 and The Employment Agreement between Workers with PT. Askes (Persero). The workers'rights changes in BPJS Kesehatan requires the worker approval. Industrial disputes can be resolved through bipartite mechanism, non-litigation and litigation.
\end{abstract}

Keywords: BPJS Kesehatan, Askes workers rights.

\section{Intisari}

Artikel ini membahas tentang perlindungan hak pekerja Askes pasca pembubaran PT Askes (Persero) tanpa likuidasi dimana pekerja Askes beralih menjadi Pekerja BPJS Kesehatan. Penelitian ini bersifat yuridis normatif yang menggunakan data sekunder. Hasil penelitian menunjukkan bahwa perlindungan hak-hak pekerja Askes pasca pembubaran PT Askes (Persero) berdasarkan UU No. 13 Tahun 2003 dan Perjanjian Kerja antara Pekerja dengan PT Askes (Persero) dimana perubahan hak-hak pekerja memerlukan persetujuan dari Pekerja. Perselisihan hubungan industrial dapat timbul akibat pembubaran PT Askes (Persero) dapat diselesaikan melalui mekanisme bipartit, non litigasi maupun litigasi.

Kata Kunci: BPJS Kesehatan, hak pekerja Askes.

\section{Pokok Muatan}

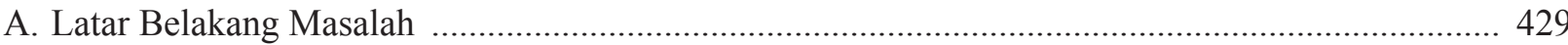

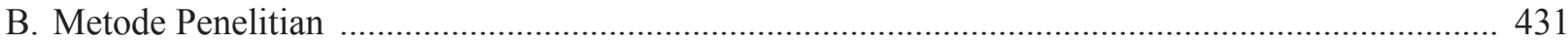

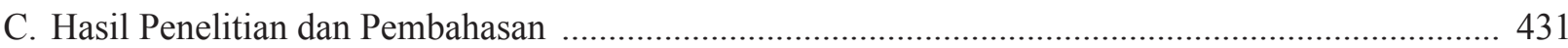

1. Akibat Hukum Pembubaran Askes dan Pembentukan BPJS Kesehatan terhadap Hubungan

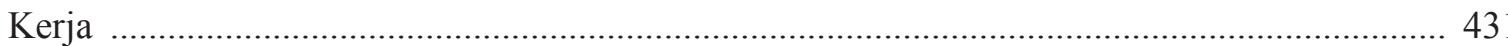

2. Perlindungan Hak-Hak Pekerja Askes Pasca Pembubaran PT Askes (Persero) ......................... 438

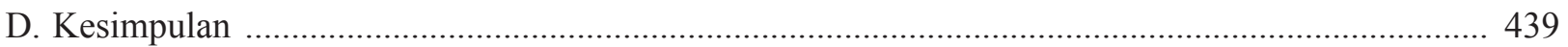

\footnotetext{
Hasil Penelitian yang dibiayai oleh DIKTI sesuai dengan Surat DP2PM DIKTI Nomor 0972/E5.1/PE/2014.

Alamat korespondensi: hasudungan_r@yahoo.com

*** Alamat korespondensi: theresia unpri@yahoo.com

**** Alamat korespondensi: rahmayanti888@yahoo.com

***** Alamat korespondensi: suratbuatbraja@yahoo.co.id
} 


\section{A. Latar Belakang Masalah}

Pasal 28H ayat (1), ayat (2), dan ayat (3) dan Pasal 34 ayat (1) dan ayat (2) Undang-Undang Dasar Negara Republik Indonesia Tahun 1945 telah mengamanatkan pembentukan sistem jaminan sosial nasional sebagai program nasional yang bertujuan memberikan kepastian perlindungan dan kesejahteraan sosial bagi seluruh rakyat Indonesia yang merupakan salah satu hak asasi manusia. ${ }^{1}$

Upaya pemerintah membentuk jaminan sosial dilakukan melalui beberapa badan usaha seperti: (1) PT Askes (Persero) jaminan pemeliharaan kesehatan bagi Pegawai Negeri Sipil, Penerima Pensiun PNS dan TNI/POLRI, Veteran, Perintis Kemerdekaan beserta keluarganya dan Badan Usaha lainnya; (2) PT Jamsostek (Persero) yang jaminan sosial bagi pekerja; (3) PT TASPEN (Persero) yang menyelenggarakan Program Dana Pensiun dan Tabungan Hari Tua; dan (4) PT ASABRI (Persero) yang menyelenggarakan asuransi social bagi seluruh prajurit TNI, anggota Polri dan Pegawai Negeri Sipil Kemhan/Polri dan Pensiunan.

Sistem jaminan sosial nasional mengalami lompatan yang besar dengan terbentuknya UndangUndang Nomor 40 Tahun 2004 tentang Sistem Jaminan Sosial Nasional (selanjutnya disebut UU No. 40 Tahun 2004) yang bertujuan untuk memberikan memberikan kepastian perlindungan dan kesejahteraan sosial bagi seluruh rakyat Indonesia. Untuk mewujudkan tujuan sistem jaminan sosial nasional tersebut, Pasal 5 ayat (1) dan Pasal 52 UU No. 40 Tahun 2004 mengamanatkan transformasi badan hukum PT Askes (Persero), PT Jamsostek (Persero), PT TASPEN (Persero), dan PT ASABRI (Persero) menjadi Badan Penyelenggara Jaminan Sosial. Amanat pembentukan Badan
Penyelenggara Jaminan Sosial tersebut ditindaklanjuti melalui Undang-Undang Nomor 24 Tahun 2011 tentang Badan Penyelenggara Jaminan Sosial (selanjutnya disebut UU No. 24 Tahun 2011) dengan membentuk: Pertama, BPJS Kesehatan. BPJS Kesehatan menyelenggarakan program jaminan kesehatan yang mulai beroperasional sejak tanggal 1 Januari 2014. BPJS Kesehatan merupakan hasil perubahan dari PT Askes (Persero) dimana PT Askes (Persero) dinyatakan bubar tanpa likuidasi dimana aset, liabilitas dan pegawai PT Askes (Persero) beralih kepada BPJS Kesehatan sejak BPJS Kesehatan mulai beroperasional. ${ }^{2}$ Jumlah pekerja Jamsostek pada saat pembubaran sebanyak 2.975 orang. $^{3}$ Kedua, BPJS Ketenagakerjaan. BPJS Ketenagakerjaan menyelenggarakan program jaminan kecelakaan kerja, jaminan hari tua, jaminan pensiun, dan jaminan kematian sejak tanggal 1 Januari 2014. BPJS Ketenagakerjaan tersebut merupakan hasil perubahan dari PT Jamsostek (Persero) dimana PT Jamsostek (Persero) dinyatakan bubar tanpa likuidasi dimana aset, liabilitas dan pegawai PT Jamsostek (Persero) beralih kepada BPJS Ketenagakerjaan sejak BPJS Ketenagakerjaan mulai beroperasional. ${ }^{4}$ Jumlah pekerja Jamsostek pada saat pembubaran sekitar 3.300 orang. 5 Selain itu, PT TASPEN (Persero), dan PT ASABRI (Persero) juga berkewajiban untuk melakukan pengalihan aset dan liabilitas kepada BPJS Ketenagakerjaan paling lambat tahun 2029.

Bila dibandingkan dengan jaminan ketenagakerjaan, layanan jaminan kesehatan memiliki beban pembiayaan yang lebih besar karena jumlah peserta lebih besar mencakup seluruh warga negara, baik yang bekerja maupun yang tidak bekerja. Jumlah peserta BPJS Kesehatan pada tanggal 1 Januari 2014

Rudi Hendra Pakpahan dan Namsihombing, “Tanggung Jawab Negara dalam Pelaksanaan Jaminan Sosial”, Jurnal Legislasi Indonesia, Vol. 9, No. 2, Juli 2012, hlm. 173

Pasal 60 ayat (3) Undang-Undang Nomor 24 Tahun 2011tentang Badan Penyelenggara Jaminan Sosial (Lembaran Negara Republik Indonesia Tahun 2011 Nomor 2011 Tambahan Lembaran Negara Republik Indonesia Nomor 116).

Yalis Ilyas, "BPJS Kedodoran; Rekrutmen SDM Terlambat?", http://kesehatan.kompasiana.com/medis/2014/02/15/bpjs-kedodoranrekruitment-sdm-terlambaaat-632166.html, diakses 17 Juli 2014.

Pasal 62 ayat (2) Undang-Undang Nomor 24 Tahun 2011 tentang Badan Penyelenggara Jaminan Sosial (Lembaran Negara Republik Indonesia Tahun 2011 Nomor 2011 Tambahan Lembaran Negara Republik Indonesia Nomor 116).

Bsi, "Migrasi BPJS 2014: Jamsostek Tak Akan Pangkas Karyawan", http://www.jamsostek.co.id/content/news.php?id=2811, diakses 5 Agustus 2014. 
sebanyak 116.122.065 jiwa yang terdiri dari peserta pengalihan sebanyak 112.592.141 jiwa, terdiri atas pengalihan dari Askes sebanyak 16.142.615 jiwa, Jamkesmas sebanyak 86,4 juta jiwa, TNI sebanyak 859.216 jiwa, Polri sebanyak 743.454 jiwa, dan Jamsostek sebanyak 8.446 .856 jiwa. Selain itu terdapat peserta baru sebanyak 112.592 .141 jiwa. $^{6}$ Sedangkan BPJS Ketenagakerjaan memiliki jumlah peserta sebanyak 31.981.948 dengan 12.041.995 sebagai peserta aktif dan 19.939.993 sebagai peserta tidak aktif. ${ }^{7}$

Pembiayaan layanan kesehatan yang semakin meningkat dari waktu ke waktu dan semakin membebani pemerintah, dunia usaha maupun masyarakat pada umumnya. Oleh karena itu, sebagian besar negara memilih model pembiayaan layanan kesehatan yang dapat dikategorikan sebagai berikut: Pertama, model asuransi kesehatan sosial (social health insurance). Model ini dirintis di Jerman sejak tahun 1882 dan berkembang di Eropa, Jepang dan negara-negara Asia lainnya seperti Filipina dan Taiwan. Kelebihan sistem ini dimana kemungkinan cakupan $100 \%$ penduduk dan relatif rendahnya peningkatan pelayanan kesehatan. Kedua, model asuransi kesehatan komersial (commercial/private health insurance). Model ini berkembang di Amerika Serikat, namun sistem ini hanya mencakup $62 \%$ penduduk. Ketiga, model National Health Services. Model ini dirintis pemerintah Inggris pasca perang dunia kedua. Model ini membuka peluang cakupan 100\% penduduk namun pembiayaan yang dijamin melalui anggaran pemerintah membuat beban pemerintah yang berat. $^{8}$

Model layanan kesehatan sebagai bagian dari jaminan sosial di Indonesia diatur dalam Pasal 19 ayat (2) UU No. 40 Tahun 2004 menyatakan bahwa jaminan kesehatan diselenggarakan dengan tujuan menjamin agar peserta memperoleh manfaat pemeliharaan kesehatan dan perlindungan dalam memenuhi kebutuhan dasar kesehatan yang diselenggarakan prinsip asuransi dan prinsip ekuitas. Prinsip ekuitas adalah kebersamaan dalam memperoleh pelayanan sesuai dengan kebutuhan medisnya yang tidak terikat dengan besaran iuran yang dibayarkan. ${ }^{9}$ Pasal 20 UU No. 40 Tahun 2004 menambahkan bahwa peserta jaminan kesehatan adalah setiap orang yang telah membayar iuran atau iuran yang dibayar oleh pemerintah. Dengan demikian jaminan sosial kesehatan yang diadopsi oleh UU No. 40 Tahun 2004 ini mengadopsi asuransi kesehatan sosial dimana iuran masyarakat yang miskin dibayar pemerintah yang bersumber dari dana publik. ${ }^{10}$

Asuransi kesehatan sosial yang diselenggarakan BPJS Kesehatan memberikan dampak terhadap 2.975 orang pekerja Askes karena Askes dinyatakan bubar setelah BPJS Kesehatan beroperasional dan seluruh pekerja Askes beralih menjadi pekerja BPJS Kesehatan. Dengan demikian, hubungan kerja yang selama ini terjalin antara pekerja Askes dengan PT Askes (Persero) beralih kepada BPJS Kesehatan. Walaupun UU No. 24 Tahun 2011 telah mengatur tentang peralihan hubungan kerja pasca terbentuknya BPJS Kesehatan, namun UU No. 24 Tahun 2011 tidak mengatur tentang hak-hak pekerja Askes pasca pengalihan hubungan kerja tersebut. Hal tersebut juga tidak diatur Pasal 163 UU No. 13 Tahun 2003 yang hanya mengatur tentang perubahan status, penggabungan, peleburan, atau perubahan kepemilikan perusahaan.

Ketidakpastian mengenai perlindungan hak-hak pekerja Askes pasca pembentukan BPJS Kesehatan membuat pekerja khawatir atas hak-

\footnotetext{
Redaksi Tempo, "Jumlah Peserta BPJS Kesehatan 116 Juta", http://www.tempo.co/read/news/2013/12/30/173541047/Jumlah-Peserta-BPJSKesehatan-116-Juta, diakses 14 Juli 2014.

BPJS Ketenagakerjaan, "Kepesertaan”, http://www.bpjsketenagakerjaan.go.id/content/i.php? mid=5\&id=144, diakses 5 Agustus 2014 .

Yohanes Budi Sarwo, "Asuransi Kesehatan Sosial sebagai Model Pembiayaan Kesehatan Menuju Jaminan Semesta (Universal Coverage)", Jurnal Masalah-Masalah Hukum, Vol. 41, No. 3, Juli 2012, hlm. 445 - 446.

Penjelasan Pasal 19 ayat (2) Undang-Undang Nomor 40 Tahun 2004 tentang Sistem Jaminan Sosial Nasional (Lembaran Negara Republik Indonesia Tahun 2004 Nomor 150, Tambahan Lembaran Negara Republik Indonesia Nomor 4456).

10 Mujibussalim, Sanusi dan Fikri, "Jaminan Sosial Kesehatan: Integrasi Program Jaminan Kesehatan Aceh dalam Sistem Jaminan Sosial Nasional”, Jurnal Dinamika Hukum, Vol. 13, No. 2, Mei 2013, hlm. 232.
} 
haknya pasca pembentukan BPJS Kesehatan sehingga dapat mempengaruhi pekerja dalam mempersiapkan operasional BPJS Kesehatan dalam memberikan layanan jaminan kesehatan bagi seluruh warga negara Indonesia. Berdasarkan latar belakang masalah di atas dapat dirumuskan permasalahan sebagai berikut: Pertama, bagaimana akibat hukum pembubaran PT Askes (Persero) terhadap hubungan kerja? Kedua, bagaimana perlindungan hak-hak pekerja Askes pasca pembubaran PT Askes (Persero)?

\section{B. Metode Penelitian}

Penelitian ini bersifat deskriptif analitis dimana peneliti akan menggambarkan permasalahan hukum yang berkaitan dengan perlindungan hak-hak Pekerja Askes pasca terbentuknya BPJS Kesehatan. Pendekatan yang digunakan adalah pendekatan yuridis normatif, yaitu pendekatan dengan melihat dari segi yuridis (peraturan-peraturan atau normanorma yang berlaku).

Penelitian ini menggunakan data sekunder yang diperoleh dari berbagai peraturan perundangan yang berkaitan pembentukan BPJS dan perlindungan hak-hak pekerja seperti UU No. 40 Tahun 2004 tentang Sistem Jaminan Sosial Nasional, UU No. 24 Tahun 2011 tentang Badan Penyelenggara Jaminan Sosial, UU No. 40 Tahun 2007 tentang Perseroan Terbatas, UU No. 13 Tahun 2003 tentang Ketenagakerjaan. Peraturan perundangan tersebut disusun untuk selanjutnya disistematisir sehingga dapat digunakan untuk pembahasan permasalahan. Penarikan kesimpulan dilakukan setelah terkumpulnya hasil analisis data dan selanjutnya dibuat kesimpulan berdasarkan hasil analisis tersebut.

\section{Hasil Penelitian dan Pembahasan}

1. Akibat Hukum Pembubaran Askes dan Pembentukan BPJS Kesehatan Terhadap Hubungan Kerja

Pada awalnya, hubungan kerja antara pekerja dengan majikan (perusahaan) diserahkan sepenuhnya pada mekanisme hukum perdata melalui perjanjian kerja. ${ }^{11}$ Ketergantungan pekerja yang sangat besar kepada pengusaha menimbulkan disparitas sehingga pekerja berada di bawah dan majikan berada di atas pekerja. Kondisi ini menimbulkan potensi eksploitasi oleh pengusaha kepada pekerja yang berada di bawah. Oleh karena itu, pemerintah melakukan intervensi untuk melindungi pekerja dari kesewenangan yang dapat dilakukan oleh pengusaha. ${ }^{12}$ Intervensi pemerintah tercermin dari diadopsinya konsep welfare state (negara kesejahteraan) pada Bab IV UUD 1945..$^{13}$ Konsep negara kesejahteraan memunculkan gagasan dalam aspek ketenagakerjaan bahwa adanya perbedaan kelas sosial antara pekerja dan pengusaha sehingga diperlukan campur tangan dalam bentuk kebijakan. ${ }^{14}$ Salah satu kebijakan yang memberikan keseimbangan kedudukan antara pekerja dan pengusaha melalui hubungan kerja diatur dalam Undang-Undang Nomor 13 Tahun 2003 tentang Ketenagakerjaan (selanjutnya disebut UU No. 13 Tahun 2003).

Undang-undang Ketenagakerjaan memberikan ketentuan normatif sejak awal hubungan kerja, selama hubungan kerja dan akhir hubungan kerja. Di awal hubungan kerja, UU No. 13 Tahun 2003 mengatur dasar hubungan kerja yaitu perjanjian kerja antara pekerja dengan pengusaha baik secara lisan maupun tulisan. ${ }^{15}$ Perjanjian kerja tersebut harus memenuhi 4 (empat) syarat yaitu: (1) kesepakatan kedua belah pihak; (2) kemampuan atau kecakapan melakukan perbuatan hukum;

Lalu Husni, 2008, Pengantar Hukum Ketenagakerjaan Indonesia, Raja Grafindo Persada, Jakarta, hlm. 20-23.

Ari Hernawan, "Hukum dan Kekuasaan dalam Hubungan Industrial”, Jurnal Mimbar Hukum, Edisi Khusus November 2011, hlm. 90.

Jimly Asshiddiqie, 2010, Konstitusi Ekonomi, Penerbit Buku Kompas, Jakarta, hlm. 340.

Budi Santoso, “Justifikasi Efisiensi sebagai Alasan Pemutusan Hubungan Kerja”, Jurnal Mimbar Hukum, Vol. 25, No. 3, Oktober 2013, hlm. 405.

15 Pasal 50 jo. Pasal 51 Undang-Undang Nomor 13 Tahun 2003 tentang Ketenagakerjaan (Lembaran Negara Republik Indonesia Tahun 2003 Nomor 49, Tambahan Lembaran Negara Republik Indonesia Nomor 4279). 
(3) adanya pekerjaan yang diperjanjikan; dan (4) pekerjaan yang diperjanjikan tidak bertentangan dengan ketertiban umum, kesusilaan, dan peraturan perundang-undangan yang berlaku. ${ }^{16}$ Dalam hal perjanjian kerja dibuat secara tertulis maka perjanjian kerja harus mencantumkan: (a) nama, alamat perusahaan, dan jenis usaha; (b) nama, jenis kelamin, umur, dan alamat pekerja/buruh; (c) jabatan atau jenis pekerjaan; (d) tempat pekerjaan; (e) besarnya upah dan cara pembayarannya; (f) syarat-syarat kerja yang memuat hak dan kewajiban pengusaha dan pekerja/buruh; (g) mulai dan jangka waktu berlakunya perjanjian kerja; dan (h) tempat dan tanggal perjanjian kerja dibuat; dan (i) tanda tangan para pihak dalam perjanjian kerja. ${ }^{17}$ Perjanjian kerja yang memenuhi syarat-syarat tersebut mengakibatkan munculnya hubungan kerja antara pekerja dengan pengusaha.

Selama hubungan kerja berlangsung, UU No. 13 Tahun 2003 memberikan perlindungan yang seimbang antara pekerja dan pengusaha. Salah satu contoh intervensi pemerintah dalam hubungan industrial adalah terkait dengan kesejahteraan pekerja seperti pengupahan, waktu kerja, keselamatan dan kesehatan kerja dan hak untuk berserikat. Selain itu, UU No. 13 Tahun 2003 juga mengatur tentang pengawasan dan penegakan hukum ketenagakerjaan, ${ }^{18}$ yang bertujuan untuk mendukung konsep negara kesejahteraan.

Hubungan kerja antara pengusaha dan pekerja cepat atau lambat hubungan kerja pasti akan berakhir karena beberapa hal, yaitu:

(a) Hubungan kerja berakhir demi hukum. Dalam hal ini baik pekerja dan pengusaha hanya bersifat pasif, artinya hubungan kerja antara pekerja dan pengusaha berakhir dengan sendirinya. Berakhirnya hubungan kerja demi hukum dapat terjadi dalam hal berakhirnya perjanjian kerja waktu tertentu, pekerja mencapai usia pensiun sebagaimana diatur dalam peraturan perusahaan, perjanjian kerja bersama atau peraturan perundangan atau pekerja meninggal dunia.

(b) Berakhirnya hubungan kerja melalui pemutusan hubungan kerja oleh pekerja. Dalam hal ini pekerja bersifat aktif dalam memutuskan hubungan kerja, yaitu:

(1) Pekerja mengundurkan diri berdasarkan kemauan sendiri;

(2) Pekerja mengajukan permohonan pemutusan hubungan kerja kepada lembaga penyelesaian perselisihan hubungan industrial dengan alasan pengusaha melakukan perbuatan seperti (a) menganiaya, menghina secara kasar atau mengancam pekerja/ buruh; (b) membujuk dan/atau menyuruh pekerja/buruh untuk melakukan perbuatan yang bertentangan dengan peraturan perundang-undangan; (c) tidak membayar upah tepatpada waktu yang telah ditentukan selama 3 (tiga) bulan berturut-turut atau lebih; (d) tidak melakukan kewajiban yang telah dijanjikan kepada pekerja/buruh; (e) memerintahkan pekerja/buruh untuk melaksanakan pekerjaan di luar yang diperjanjikan, atau (f) memberikan pekerjaan yang membahayakan jiwa, keselamatan, kesehatan dan kesusilaan pekerja/buruh se-

16 Pasal 52 ayat (1) Undang-Undang Nomor 13 Tahun 2003 tentang Ketenagakerjaan (Lembaran Negara Republik Indonesia Tahun 2003 Nomor 49, Tambahan Lembaran Negara Republik Indonesia Nomor 4279).

17 Pasal 54 ayat (1) Undang-Undang Nomor 13 Tahun 2003 tentang Ketenagakerjaan (Lembaran Negara Republik Indonesia Tahun 2003 Nomor 49, Tambahan Lembaran Negara Republik Indonesia Nomor 4279).

18 Saprudin, "Sosialisering Process Hukum Perburuhan dalam Aspek Kebijakan Pengupahan”, Jurnal Mimbar Hukum, Vol. 24, No. 3, Oktober 2012, hlm. 544 . 
dangkan pekerjaan tersebut tidak dicantumkan pada perjanjian kerja. ${ }^{19}$

(3) Pekerja yang mengalami sakit berkepanjangan, mengalami cacat akibat kecelakaan kerja dan tidak dapat melakukan pekerjaannya setelah melampaui batas 12 (dua belas) bulan; ${ }^{20}$ atau

(4) Pekerja tidak bersedia melanjutkan hubungan kerja karena Perusahaan mengalami perubahan status, penggabungan, peleburan atau perubahan kepemilikan. ${ }^{21}$

(c) Berakhirnya hubungan kerja melalui pemutusan hubungan kerja oleh pengusaha. Dalam hal ini Pemberi Kerja bersifat aktif dalam memutuskan hubungan kerja karena:

(1) Pekerja terbukti melakukan kesalahan berat sebagaimana diatur dalam Pasal 158 UU No. 13 Tahun 2003, seperti: (a) melakukan penipuan, pencurian, atau penggelapan barang dan/ atau uang milik perusahaan; (b) memberikan keterangan palsu atau yang dipalsukan sehingga merugikan perusahaan; (c) mabuk, meminum minuman keras yang memabukkan, memakai dan/atau mengedarkan narkotika, psikotropika, dan zat adiktif lainnya di lingkungan kerja; (d) melakukan perbuatan asusila atau perjudian di lingkungankerja;(e)menyerang, menganiaya, mengancam, atau mengintimidasi teman sekerja atau pengusaha di lingkungan kerja; (f) membujuk teman sekerja atau pengusaha untuk melakukan perbuatan yang bertentangan dengan peraturan perundang-undangan; dengan ceroboh atau sengaja merusak atau membiarkan dalam keadaan bahaya barang milik perusahaan yang menimbulkan kerugian bagi perusahaan; (h) dengan ceroboh atau sengaja membiarkan teman sekerja atau pengusaha dalam keadaan bahaya di tempat kerja; (i) membongkar atau membocorkan rahasia perusahaan yang seharusnya dirahasiakan kecuali untuk kepentingan negara, atau (j) melakukan perbuatan lainnya di lingkungan perusahaan yang diancam pidana penjara 5 (lima) tahun atau lebih.

(2) Pekerja yang setelah 6 (enam) bulan tidak dapat melakukan pekerjaan karena ditahan pihak berwajib karena diduga melakukan tindak pidana bukan atas pengaduan Pengusaha.

(3) Pekerja dinyatakan bersalah melakukan tindak pidana oleh Pengadilan.

(4) Pekerja melakukan pelanggaran yang diatur dalam perjanjian

19 Pasal 169 Undang-Undang Nomor 13 Tahun 2003 tentang Ketenagakerjaan (Lembaran Negara Republik Indonesia Tahun 2003 Nomor 49, Tambahan Lembaran Negara Republik Indonesia Nomor 4279).

20 Pasal 172 Undang-Undang Nomor 13 Tahun 2003 tentang Ketenagakerjaan (Lembaran Negara Republik Indonesia Tahun 2003 Nomor 49, Tambahan Lembaran Negara Republik Indonesia Nomor 4279).

21 Pasal 163 Undang-Undang Nomor 13 Tahun 2003 tentang Ketenagakerjaan (Lembaran Negara Republik Indonesia Tahun 2003 Nomor 49, Tambahan Lembaran Negara Republik Indonesia Nomor 4279). 
kerja, peraturan perusahaan, atau perjanjian kerja bersama.

(5) Pekerja mangkir selama 5 (lima) hari secara berurut-turut. ${ }^{22}$

(6) Perusahaan mengalami kondisi tertentu, misalnya perusahaan mengalami perubahan status, penggabungan, peleburan atau perubahan kepemilikan, perusahaan tutup karena mengalami kerugian secara terus menerus selama 2 (dua) tahun atau keadaan memaksa (force majure) atau perusahaan dinyatakan pailit.

Dalam praktiknya, dinamika hubungan kerja antara pekerja dan perusahaan dapat terjadi karena restrukturisasi perusahaan. Undang-Undang Nomor 40 Tahun 2007 tentang Perseroan Terbatas (selanjutnya disebut UU No. 40 Tahun 2007) mengakomodir restrukturisasi tersebut melalui 4 (empat) cara, yaitu:

a. Penggabungan yaitu perbuatan hukum yang dilakukan oleh satu perseroan atau lebih untuk menggabungkan diri dengan perseroan lain yang telah ada yang mengakibatkan aktiva dan pasiva dari perseroan yang menggabungkan diri beralih karena hukum kepada Perseroan yang menerima penggabungan dan selanjutnya status badan hukum Perseroan yang menggabungkan diri berakhir karena hukum. ${ }^{23}$ Penggabungan perusahaan tersebut dilatarbelakangi oleh beberapa hal seperti keuntungan biaya (cost advantage), penurunan resiko (lower risk), meminimalkan penundaan operasi (fewer operating delays), menghindari pengambilalihan (avoidance of take overs) dan perolehan aset tidak berwujud (acquisition of intangible assets).$^{24}$ Salah satu contoh penggabungan perusahaan dapat dilihat dari penggabungan beberapa bank untuk menindaklanjuti kebijakan Bank Indonesia yang mengeluarkan single present policy. ${ }^{25}$ Penggabungan pada perbankan dilakukan dengan cara penggabungan usaha dua atau lebih bank dengan cara mempertahankan berdirinya salah satu bank dan melikuidasi bank-bank lainnya. Pelaksanaan penggabungan tersebut dapat dilakukan dengan pembelian seluruh saham suatu bank oleh bank lainnya dengan mengadakan perjanjian penggabungan perusahaan. $^{26}$ Salah satu contoh penggabungan perusahaan adalah PT Bank Lippo Tbk menggabungkan diri kepada PT Bank CIMB Niaga Tbk. dengan tanggal efektif penggabungan 1 Oktober 2008. Pada tanggal 3 Juni 2008, Pekerja Bank Lippo diberikan pilihan bergabung dengan PT Bank CIMB Niaga Tbk. atau mengundurkan diri pada tanggal efektif penggabungan. Pekerja Bank Lippo yang memilih untuk mengundurkan diri memperoleh pesangon sebesar 1 (satu) kali sesuai ketentuan Pasal 156 ayat (2), uang

22 Pasal 158 ayat (1) Undang-Undang Nomor 13 Tahun 2003 tentang Ketenagakerjaan (Lembaran Negara Republik Indonesia Tahun 2003 Nomor 49, Tambahan Lembaran Negara Republik Indonesia Nomor 4279).

23 Pasal 1 butir 9 Undang-Undang Nomor 40 Tahun 2007 tentang Perseroan Terbatas (Lembaran Negara Republik Indonesia Tahun 2007 Nomor 106, Tambahan Lembaran Negara Republik Indonesia Nomor 4756).

24 Rosita, "Penggabungan Usaha, Laporan Keuangan Konsolidasi dan Investasi Perusahaan Asosiasi", Jurnal Graduasi, Vol. 26, Edisi November 2011, hlm. 92.

25 Johannes Ibrahim, 2008, "Penerapan Single Presence Policy dan Dampaknya bagi Perbankan Nasional”, Jurnal Hukum Bisnis, Vol. 27, No. 2 2008, hlm. 5.

26 Felix Oentong Soebagjo, "Kajian Hukum Bisnis atas UU No. 40 Tahun 2007 tentang Perseroan Terbatas”, Jurnal Hukum Bisnis, Vol. 26, No. 3,2007 , hlm. 54 
perhargaan masa kerja 1 (satu) kali ketentuan Pasal 156 ayat (3) dan uang penggantian hak sesuai ketentuan dalam Pasal 156 ayat (4) UU No. 13 Tahun 2003. Pekerja yang memilih bergabung dengan PT Bank CIMB Niaga Tbk. maka Perjanjian Pengalihan Karyawan yang ditandatangani oleh Pekerja Bank Lippo, PT Bank CIMB Niaga Tbk dan PT Bank Lippo Tbk. Perjanjian tersebut ditandatangani sebelum tanggal efektif penggabungan dan berlaku sejak tanggal efektif penggabungan. Berkaitan dengan perlindungan hak-hak pekerja maka Pasal 3 Perjanjian Pengalihan Hubungan kerja yang menyatakan sebagai berikut "Terhitung sejak Tanggal Efektif Penggabungan sampai dengan proses harmonisasi upah dan manfaat selesai dilakukan oleh CIMB Niaga, nilai upah dan manfaat yang diterima oleh Karyawan akan tetap sama dengan upah dan manfaat yang diterima oleh Karyawan sebelum Tanggal Efektif Penggabungan sesuai perincian di bawah ini yang dibuat oleh LB dan disetujui oleh Karyawan". ${ }^{27}$ Jumlah pekerja yang terlibat dalam penggabungan diri tersebut sebanyak 10.560 yang mewakili 96\% dari gabungan pekerja Bank Niaga dan Bank Lippo. ${ }^{28}$

b. Peleburan yaitu perbuatan hukum yang dilakukan oleh dua perseroan atau lebih untuk meleburkan diri dengan cara mendirikan satu perseroan baru yang karena hukum memperoleh aktiva dan pasiva dari perseroan yang meleburkan diri dan status badan hukum perseroan yang meleburkan diri berakhir karena hukum. ${ }^{29}$ Peleburan perusahaan dapat dilihat dari peleburan 5 (lima) bank yaitu: PT Bank Bali Tbk., PT Bank Universal Tbk., PT Bank Artamedia, PT Bank Patriot dan PT Bank Prima Ekspress menjadi PT Bank Permata, Tbk. pada tahun 2002. Contoh lainnya adalah PT Bank Mandiri yang merupakan hasil penggabungan 4 (empat) bank yaitu Bank Bumi Daya, Bank Dagang Negara, Bank Pembangunan Indonesia, Bank Ekspor Impor Indonesia. Dalam hal ini, hubungan kerja mengalami perubahan dimana hubungan kerja antara pekerja masing-masing bank beralih kepada PT Bank Mandiri setelah tanggal efektif peleburan.

c. Pengambilalihan yaitu perbuatan hukum yang dilakukan oleh badan hukum atau orang perseorangan untuk mengambil alih saham perseroan yang mengakibatkan beralihnya pengendalian atas perseroan tersebut. ${ }^{30}$ Pengambalihan dapat dilihat dari kasus Temasek Holding yang mengambilalih PT Telekomunikasi Selular Tbk. dan PT Indosat oleh Temasek Holding Company melalui anak usahanya. ${ }^{31}$ Dalam hal ini tidak terjadi perubahan hubungan kerja karena perusahaan hanya mengalami perubahan kepemilikan saham saja.

Perjanjian Pengalihan Karyawan antara PT Bank CIMB Niaga TBk, Ronald Hasudungan Sianturi dan PT Bank Lippo Tbk.

Septiamitha, Friska, 2012, Analisis Kinerja Penggabungan Usaha pada Bank CIMB Niaga, Tesis, Program Magister Akuntansi Fakultas Ekonomika dan Bisnis Universitas Kristen Satya Wacana, Salatiga, hlm. 2.

29 Pasal 1 butir 10 Undang-Undang Nomor 40 Tahun 2007 tentang Perseroan Terbatas (Lembaran Negara Republik Indonesia Tahun 2007 Nomor 106, Tambahan Lembaran Negara Republik Indonesia Nomor 4756).

30 Pasal 1 butir 11 Undang-Undang Nomor 40 Tahun 2007 tentang Perseroan Terbatas (Lembaran Negara Republik Indonesia Tahun 2007 Nomor 106, Tambahan Lembaran Negara Republik Indonesia Nomor 4756).

31 L. Budi Kagramanto, "Kepemilikan Silang Saham PT Indosat dan PT Telkomsel oleh Temasek Holding Company", Jurnal Mimbar Hukum, Vol. 20, No. 1, Februari 2008, hlm. 2. 
d. Pemisahan yaitu perbuatan hukum yang dilakukan oleh perseroan untuk memisahkan usaha yang mengakibatkan seluruh aktiva dan pasiva perseroan beralih karena hukum kepada dua perseroan atau lebih atau sebagian aktiva dan pasiva perseroan beralih karena hukum kepada satu perseroan atau lebih. ${ }^{32}$ Pemisahan perusahaan dapat dilihat dari berbagai bank yang telah melepaskan unit usaha syariah menjadi bank syariah seperti BNI Syariah yang berasal dari Divisi Unit Usaha Syariah BNI, BRI Syariah yang berasal dari Divisi Unit Usaha Syariah BRI. Pemisahan perusahaan diikuti dengan perjanjian pengalihan hubungan kerja yang melibatkan pekerja, perusahaan yang memisahkan diri dan perusahaan hasil pemisahan. Penandatangan perjanjian tersebut dilakukan sebelum tanggal efektif pemisahan yang melibatkan pekerja, perusahaan yang memisahkan diri maupun perusahaan hasil pemisahan.

Berkaitan dengan restrukturisasi tersebut, Pasal 163 UU No. 13 Tahun 2003 memberikan pilihan kepada perusahaan maupun pekerja untuk menentukan kelanjutan hubungan kerja pasca restrukturisasi perusahaan sebagai berikut:

(1) Pengusaha dapat melakukan pemutusan hubungan kerja terhadap pekerja/buruh dalam hal terjadi perubahan status, penggabungan, peleburan, atau perubahan kepemilikan perusahaan dan pekerja/buruh tidak bersedia melanjutkan hubungan kerja, maka pekerja/buruh berhak atas uang pesangon sebesar 1 (satu) kali sesuai ketentuan Pasal 156 ayat (2), uang perhargaan masa kerja 1 (satu) kali ketentuan Pasal 156 ayat (3) dan uang penggantian hak sesuai ketentuan dalam Pasal 156 ayat (4) UU No. 13 Tahun 2003.

(2) Pengusaha dapat melakukan pemutusan hubungan kerja terhadap pekerja/buruh karena perubahan status, penggabungan, atau peleburan perusahaan, dan pengusaha tidak bersedia menerima pekerja/buruh di perusahaannya, maka pekerja/buruh berhak atas uang pesangon sebesar 2 (dua) kali ketentuan Pasal 156 ayat (2), uang penghargaan masa kerja 1 (satu) kali ketentuan dalam Pasal 156 ayat (3), dan uang penggantian hak sesuai ketentuan dalam Pasal 156 ayat (4) UU No. 13 Tahun 2003.

PT Askes (Persero) merupakan Badan Usaha Milik Negara yang ditugaskan khusus oleh pemerintah untuk menyelenggarakan jaminan pemeliharaan kesehatan bagi Pegawai Negeri Sipil, Penerima Pensiun PNS dan TNI/POLRI, Veteran, Perintis Kemerdekaan beserta keluarganya dan Badan Usaha lainnya. Sejarah PT Askes (Persero) dimulai pada tahun 1968 melalui Keputusan Presiden Nomor 230 Tahun 1968 yang membentuk Badan Penyelenggara Dana Pemeliharaan Kesehatan (BPDPK) untuk pemeliharaan kesehatan bagi Pegawai Negeri dan Penerima Pensiun (PNS dan ABRI) beserta anggota keluarganya. Pada tahun 1984 diterbitkan Peraturan Pemerintah Nomor 22 Tahun 1984 tentang Pemeliharaan Kesehatan bagi Pegawai Negeri Sipil, Penerima Pensiun (PNS, ABRI dan Pejabat Negara) beserta anggota keluarganya dibentuk Badan Penyelenggara Dana Pemeliharaan Kesehatan (BPDPK) mengalami perubahan Perusahaan Umum Husada Bhakti agar penyelenggaraan tersebut dilakukan secara professional. Berdasarkan Peraturan Pemerintah Nomor 69 Tahun 1991, kepesertaan program 
jaminan pemeliharaan kesehatan yang dikelola Perum Husada Bhakti ditambah dengan Veteran dan Perintis Kemerdekaan beserta anggota keluarganya. Berdasarkan Peraturan Pemerintah Nomor 6 Tahun 1992 status Perum diubah menjadi Perusahaan Perseroan (PT Persero). PT Askes (Persero) yang berkedudukan di Jakarta didirikan dengan Akte Notaris Muhani Salim, S.H. No. 104 dan 105, tanggal 20 Agustus 1992 yang telah diubah terakhir dengan Akte Notaris Nanda Fauz Iwan, S.H. tertanggal 10 Maret 2004.

PT Askes (Persero) yang berbadan hukum cakap melakukan perbuatan hukum, termasuk membuat perjanjian kerja yang mengacu pada syarat perjanjian kerja pada Pasal 52 ayat (1) UU No. 13 Tahun 2003, yaitu (1) kesepakatan para pihak, yaitu Calon Pekerja Askes dengan PT Askes (Persero); (2) kemampuan atau kecakapan melakukan perbuatan hukum yaitu Pekerja bertindak untuk diri sendiri dalam menandatangani amandemen perjanjian kerja dan Pihak PT Askes (Persero) diwakili oleh Direktur PT Askes (Persero) atau yang pihak yang diberikan kuasa; (3) adanya pekerjaan yang diperjanjikan yaitu berkaitan dengan pekerjaan yang diberikan kepada Calon Pekerja Askes ${ }^{33}$ dan (4) pekerjaan yang diperjanjikan tersebut tidak bertentangan dengan ketertiban umum, kesusilaan, dan peraturan perundang-undangan yang berlaku.

Perjanjian kerja antara Pekerja Askes dan PT Askes (Persero) merupakan dasar hubungan kerja yang tunduk pada UU No. 13 Tahun 2003. Hak dan kewajiban para pihak mengacu pada UU No. 13 Tahun 2003, termasuk pada saat PT Askes (Persero) mengalami restrukturisasi, termasuk pembubaran perusahaan. Pasal 142 UU No. 40 Tahun 2007 mengatur dasar pembubaran perseroan berdasarkan keputusan RUPS, jangka waktu berdirinya yang ditetapkan dalam anggaran dasar telah berakhir, penetapan pengadilan, dicabutnya kepailitan berdasarkan putusan pengadilan niaga yang telah mempunyai kekuatan hukum tetap, harta pailit Perseroan tidak cukup untuk membayar biaya kepailitan, harta pailit Perseroan yang telah dinyatakan pailit berada dalam keadaan insolvensi sebagaimana diatur dalam Undang-Undang tentang Kepailitan dan Penundaan Kewajiban Pembayaran Utang; atau dicabutnyaizin usaha Perseroan sehingga mewajibkan Perseroan melakukan likuidasi sesuai dengan ketentuan peraturan perundang-undangan. Pembubaran tersebut wajib diikuti dengan likuidasi yang dilakukan oleh likuidator atau kurator ${ }^{34}$ untuk menyelesaikan hak dan kewajiban kepada pihak ketiga.

Pembubaran PT Askes (Persero) yang berbentuk perseroan terbatas berlaku asas lex specialis derogat legi generalis dimana dasar pembubaran Askes adalah UU No. 24 Tahun 2011 dan pembubaran Askes tidak diikuti dengan likuidasi perusahaan, termasuk kepada Pekerja Askes dimana tidak ada pemutusan hubungan kerja dan seluruh Pekerja Askes menjadi Pekerja BPJS Kesehatan. ${ }^{35}$ Mengingat bahwa hubungan kerja memiliki dimensi hukum privat dan hukum publik maka perubahan Pekerja Askes menjadi Pekerja BPJS tidak cukup hanya berdasarkan UU No. 24 Tahun 2011 saja tetapi juga harus melibatkan hukum privat melalui amandemen perjanjian kerja yang melibatkan Pekerja, Askes dan BPJS Kesehatan yang dilakukan sebelum pembubaran Askes dan BPJS terbentuk. Amandemen perjanjian kerja tersebut harus mengacu pada syarat perjanjian kerja pada Pasal 52 ayat (1) UU No. 13 Tahun 2003, yaitu:

a. Kesepakatan para pihak, yaitu Pekerja, Askes dan BPJS Kesehatan. Dalam hal ini, kesepakatan BPJS Kesehatan diwakili oleh Komisaris dan Direksi Askes yang ditunjuk untuk

33 Pasal 169 ayat (1) Undang-Undang Nomor 13 Tahun 2003 tentang Ketenagakerjaan (Lembaran Negara Republik Indonesia Tahun 2003 Nomor 49, Tambahan Lembaran Negara Republik Indonesia Nomor 4279).

34 Pasal 142 Undang-Undang Nomor 40 Tahun 2007 tentang Perseroan Terbatas (Lembaran Negara Republik Indonesia Tahun 2007 Nomor 106, Tambahan Lembaran Negara Republik Indonesia Nomor 4756).

35 Pasal 60 ayat (3) butir c Undang-Undang Nomor 24 Tahun 2011 tentang Badan Penyelenggara Jaminan Sosial (Lembaran Negara Republik Indonesia Tahun 2011 Nomor 2011 Tambahan Lembaran Negara Republik Indonesia Nomor 116). 
mempersiapkan operasional BPJS. ${ }^{36}$

b. Kemampuan atau kecakapan melakukan perbuatan hukum.

Ketiga pihak yang menandatangani amandemen perjanjian kerja harus cakap untuk menandatangani amandemen perjanjian kerja. Pihak Pekerja bertindak untuk diri sendiri dalam menandatangani amandemen perjanjian kerja, Pihak Askes diwakili oleh Direktur Askes atau yang pihak yang diberikan kuasa, dan Pihak BPJS diwakili oleh Komisaris dan Direksi Askes yang ditunjuk untuk mempersiapkan operasional BPJS. ${ }^{37}$

c. Adanya pekerjaan yang diperjanjikan. Amandemen perjanjian kerja tersebut harus mencantumkan pekerjaan yang diberikan kepada Pekerja. Dalam hal pekerjaan yang diberikan pada BPJS berbeda dengan pekerjaan pada Askes maka Pekerja dapat mengajukan permohonan pemutusan hubungan kerja kepada lembaga penyelesaian perselisihan hubungan industrial dengan alasan pengusaha memerintahkan pekerja/buruh untuk melaksanakan pekerjaan di luar yang diperjanjikan. ${ }^{38}$

d. Pekerjaan yang diperjanjikan tidak bertentangan dengan ketertiban umum, kesusilaan, dan peraturan perundangundangan yang berlaku.

Amandemen perjanjian kerja yang melibatkan Pekerja, Askes dan BPJS Kesehatan merupakan bentuk pengalihan hubungan dan bukan pengalihan pegawai sebagaimana dinyatakan pada Pasal 58 butir b UU No. 24 Tahun 2011. Pengalihan pegawai (pekerja) merupakan bentuk perbudakan yang pelanggaran terhadap hak asasi manusia karena menempatkan manusia sebagai barang yang dapat dialihkan. Hukum ketenagakerjaan di Indonesia menempatkan pekerja sebagai manusia yang memiliki hak asasi sehingga pekerja tidak dapat dialihkan.

\section{Perlindungan Hak-Hak Pekerja Askes Pasca Pembubaran PT Askes (Persero)}

Hak-hak normatif pekerja diatur dalam berbagai peraturan perundangan sedangkan hak pekerja yang lebih baik diatur melalui perjanjian kerja. Dalam hal ini, hak normatif berdimensi hukum publik sedangkan hak pekerja yang lebih baik melalui perjanjian kerja merupakan dimensi hukum privat. Sebagai ilustrasi bahwa besarnya upah minimum propinsi diatur oleh peraturan daerah masing-masing provinsi, sedangkan upah pekerja yang lebih baik daripada upah minimum propinsi diatur pada masing-masing perjanjian kerja.

Pengalihan hubungan kerja antara Pekerja, PT Askes (Persero) dan BPJS Kesehatan diatur melalui UU No. 24 Tahun 2011 yang berdimensi hukum publik, namun hak-hak pekerja yang lebih baik dari hak normatif memiliki dimensi hukum privat sehingga perubahan terhadap hak-hak pekerja pasca operasional BPJS Kesehatan dilakukan berdasarkan kesepakatan antara Pekerja dan BPJS Kesehatan. Kesepakatan mengenai perubahan hakhak pekerja dapat dilakukan antara BPJS Kesehatan dengan masing-masing Pekerja maupun diwakili oleh Serikat Pekerja.

Menurut Elvyn G. Masaya bahwa pembubaran Askes menjadi BPJS Kesehatan memberikan beban tugas yang lebih berat kepada Pekerja BPJS karena harus mampu meng-cover seluruh pekerja baik sektor informal dan non formal. Adapun target peserta BPJS pada 2017 mampu menjamin 37 juta pekerja di seluruh Indonesia. Untuk mendukung pekerjaan tersebut maka hak-

36 Pasal 58 Undang-Undang Nomor 24 Tahun 2011 tentang Badan Penyelenggara Jaminan Sosial (Lembaran Negara Republik Indonesia Tahun 2011 Nomor 2011 Tambahan Lembaran Negara Republik Indonesia Nomor 116).

37 Pasal 58 Undang-Undang Nomor 24 Tahun 2011tentang Badan Penyelenggara Jaminan Sosial (Lembaran Negara Republik Indonesia Tahun 2011 Nomor 2011 Tambahan Lembaran Negara Republik Indonesia Nomor 116).

38 Pasal 169 ayat (1) Undang-Undang Nomor 13 Tahun 2003 tentang Ketenagakerjaan (Lembaran Negara Republik Indonesia Tahun 2003 Nomor 49, Tambahan Lembaran Negara Republik Indonesia Nomor 4279). 
hak pekerja BPJS Kesehatan telah mengalami peningkatan upah pada tahun pertama sebesar $25 \%$. Peningkatan tersebut efektif tanggal 1 Januari 2014 sesuai tanggal bubarnya Askes dan BPJS Kesehatan beroperasional. ${ }^{39}$

Pembubaran PT Askes (Persero) tersebut dapat menimbulkan perselisihan hubungan industrial lainnya seperti: (a) perselisihan hak, yaitu perselisihan yang timbul karena tidak dipenuhinya hak, akibat adanya perbedaan pelaksanaan atau penafsiran terhadap ketentuan peraturan perundangan, atau perjanjian kerja bersama; (b) perselisihan kepentingan adalah perselisihan yang timbul dalam hubungan kerja karena tidak adanya kesesuaian pendapat mengenai pembuatan, dan/atau perubahan syarat-syarat kerja yang ditetapkan dalam perjanjian kerja, atau peraturan perusahaan atau perjanjian kerja bersama maupun; (c) perselisihan pemutusan hubungan kerja adalah perselisihan yang timbul karena tidak adanya kesesuaian pendapat mengenai pengakhiran hubungan kerja yang dilakukan salah satu pihak.

Penyelesaian perselisihan tersebut dapat dilakukan melalui beberapa cara yaitu: ${ }^{41}$

1. Penyelesaian bipartit, yaitu penyelesaian yang dilakukan oleh para pihak yang berselisih dengan cara mekanisme musyawarah untuk mufakat.

2. Penyelesaian di luar pengadilan dengan cara-cara sebagai berikut: Pertama, arbitrase yaitu penyelesaian perselisihan di luar pengadilan yang disepakati secara tertulis oleh para pihak dengan memilih arbiter tunggal atau majelis arbiter yang ditetapkan oleh Menteri Tenaga Kerja dan Transmigrasi. Perselisihan yang dapat diselesaikan melalui mekanisme ini adalah perselisihan kepentingan dan perselisihan antar serikat pekerja. Keputusan arbitrase bersifat final kecuali untuk alasan tertentu dapat diajukan pembatalan kepada Mahkamah Agung; ${ }^{40}$ Kedua, konsiliasi yaitu penyelesaian perselisihan kepentingan, perselisihan hak atau perselisihan antar Serikat Pekerja dalam satu perusahaan melalui musyawarah yang ditengahi oleh seorang atau lebih konsiliator yang netral dipilih atas kesepakatan para pihak; maupun Ketiga, mediasi yaitu penyelesaian perselisihan hak, perselisihan kepentingan, perselisihan PHK dan perselisihan antar serikat pekerja dalam satu perusahaan melalui musyawarah yang ditengahi oleh seorang atau lebih mediator yang netral.

3. Penyelesaian melalui pengadilan melalui peradilan hubungan industrial. Upaya hukum yang dapat diambil atas putusan Pengadilan Hubungan Industrial adalah upaya hukum kasasi dan upaya hukum luar biasa melalui Peninjauan Kembali (PK).

\section{Kesimpulan}

Pasal 61 butir (d) UU No. 24 Tahun 2011 yang menyatakan bahwa pengalihan Pekerja Askes menjadi Pekerja BPJS Ketenagakerjaan tidak tepat karena pekerja bukan barang yang dapat dialihkan. Hukum ketenagakerjaan di Indonesia menempatkan pekerja sebagai manusia yang memiliki hak asasi manusia dan berkedudukan sejajar dengan pengusaha dalam menjalankan perusahaan, sehingga perlu mendapatkan perlindungan pasca pembubaran

\footnotetext{
39 Nurul Julaikah, "Berubah Menjadi BPJS, Gaji Karyawan Jamsostek Naik 25 Persen”, https://id.berita.yahoo.com/berubah-menjadi-bpjs-gajikaryawan-jamsostek-naik-25-035337378.html, diakses 23 Juli 2014.

40 Pasal 51 Undang-Undang Nomor 2 Tahun 2004 tentang Penyelesaian Perselisihan Hubungan Industrial (Lembaran Negara Republik Indonesia Tahun 2004 Nomor 6, Tambahan Lembaran Negara Republik Indonesia Nomor 4356).

41 Libertus Jehani, 2006, Hak-Hak Pekerja Bila di PHK, Visi Media, Jakarta, hlm. 22-23.
} 
PT Askes (Persero). Perlindungan hak-hak Pekerja Askes pasca pembubaran PT Askes (Persero) melalui: Pertama, hukum publik berdasarkan UU No. 13 Tahun 2003 untuk mengatur hak normatif pekerja, dan Kedua, hukum privat berdasarkan Perjanjian Kerja yang mengatur tentang hak-hak pekerja sebelum pembubaran PT Askes (Persero) yang hanya dapat diubah berdasarkan kesepakatan para pihak. Dalam hal terdapat perselisihan hubungan industrial akibat pembubaran Askes dan Pembentukan BPJS Kesehatan maka perselisihan hubungan industrial tersebut diselesaikan melalui mekanisme bipartit, mekanisme non litigasi dan litigasi.

\section{DAFTAR PUSTAKA}

\section{A. Buku}

Asshiddiqie, Jimly, 2010, Konstitusi Ekonomi, Penerbit Buku Kompas, Jakarta.

Jehani, Libertus, 2006, Hak-Hak Pekerja Bila Di PHK, Visi Media, Jakarta.

Husni, Lalu, 2008, Pengantar Hukum Ketenagakerjaan Indonesia, Raja Grafindo Persada, Jakarta.

\section{B. Artikel Jurnal}

Ari Hernawan, "Hukum dan Kekuasaan dalam Hubungan Industrial", Jurnal Mimbar Hukum, Edisi Khusus November 2011.

Ibrahim, Johannes, "Penerapan Single Presence Policy dan Dampaknya bagi Perbankan Nasional”, Jurnal Hukum Bisnis, Vol. 27, No. 2, 2008 .

Kagramanto, L. Budi, “Kepemilikan Silang Saham PT. Indosat dan PT Telkomsel Oleh Temasek Holding Company", Jurnal Mimbar Hukum, Vol. 20, No. 1, Februari 2008.

Mujibussalim, Sanusi dan Fikri, "Jaminan Sosial Kesehatan: Integrasi Program Jaminan Kesehatan Aceh dalam Sistem Jaminan Sosial Nasional”, Jurnal Dinamika Hukum, Vol. 13, No. 2, Mei 2013.

Pakpahan, Rudi Hendra dan Namsihombing, "Tanggung Jawab Negara dalam Pelaksanaan Jaminan Sosial", Jurnal Legislasi Indonesia, Vol. 9, No. 2, Juli 2012.

Rosita, "Penggabungan Usaha, Laporan Keuangan Konsolidasi dan Investasi Perusahaan Asosiasi”, Jurnal Graduasi, Vol. 26, November 2011.
Santoso, Budi, "Justifikasi Efisiensi sebagai Alasan Pemutusan Hubungan Kerja”, Jurnal Mimbar Hukum, Vol. 25, No. 3, Oktober 2013.

Saprudin, "Sosialisering Process Hukum Perburuhan dalam Aspek Kebijakan Pengupahan", Jurnal Mimbar Hukum, Vol. 24, No. 3, Oktober 2012.

Sarwo, Yohanes Budi, “Asuransi Kesehatan Sosial Sebagai Model Pembiayaan Kesehatan Menuju Jaminan Semesta (Universal Coverage)", Jurnal Masalah-Masalah Hukum, Vol. 41, No. 3, Juli 2012.

Soebagjo, Felix Oentong, "Kajian Hukum Bisnis atas UU No. 40 Tahun 2007 tentang Perseroan Terbatas", Jurnal Hukum Bisnis, Vol. 26, No. $3,2007$.

\section{Hasil Penelitian/Tugas Akhir}

Septiamitha, Friska, 2012, Analisis Kinerja Penggabungan Usaha Pada Bank CIMB Niaga, Tesis, Program Magister Akuntansi Fakultas Ekonomika dan Bisnis Universitas Kristen Satya Wacana, Salatiga.

\section{Internet}

BPJS Ketenagakerjaan, "Kepesertaan", http:// www.bpjsketenagakerjaan.go.id/ content/i. php? mid $=5 \& i d=144$ diakses 5 Agustus 2014.

Bsi, "Migrasi BPJS 2014: Jamsostek Tak Akan Pangkas Karyawan", http://www.jamsostek. co.id/content/news.php?id=2811 diakses 5 Agustus 2014. 
Julaikah, Nurul, "Berubah Menjadi BPJS, gaji karyawan Jamsostek Naik 25 Persen“, https://id.berita.yahoo.com/berubahmenjadi-bpjs-gaji-karyawan-jamsosteknaik-25-035337378.html, diakses 23 Juli 2014.

Redaksi Tempo, "Jumlah Peserta BPJS Kesehatan 116 Juta", http://www.tempo.co/read/ news/2013/12/30/173541047/JumlahPeserta-BPJS-Kesehatan-116-Juta, diakses 14 Juli 2014.

Yalis Ilyas, "BPJS Kedodoran; Rekrutmen SDM Terlambat?", http://kesehatan.kompasiana. com/medis/2014/02/15/bpjs-kedodoranrekruitment-sdm-terlambaaat-632166.html, diakses 17 Juli 2014.

\section{E. Peraturan Perundang-Undangan}

Undang-Undang Dasar Negara Republik Indonesia Tahun 1945.

Undang-Undang Nomor 13 Tahun 2003 tentang Ketenagakerjaan (Lembaran Negara Republik Indonesia Tahun 2003 Nomor 49, Tambahan Lembaran Negara Republik Indonesia Nomor 4279).
Undang-Undang Nomor 2 Tahun 2004 tentang Penyelesaian Perselisihan Hubungan Industrial (Lembaran Negara Republik Indonesia Tahun 2004 Nomor 6, Tambahan Lembaran Negara Republik Indonesia Nomor 4356).

Undang-Undang Nomor 40 Tahun 2004 tentang Sistem Jaminan Sosial Nasional (Lembaran Negara Republik Indonesia Tahun 2004 Nomor 150, Tambahan Lembaran Negara Republik Indonesia Nomor 4456).

Undang-Undang Nomor 40 Tahun 2007 tentang Perseroan Terbatas (Lembaran Negara Republik Indonesia Tahun 2007 Nomor 106, Tambahan Lembaran Negara Republik Indonesia Nomor 4756).

Undang-Undang Nomor 24 Tahun 2011 tentang Badan Penyelenggara Jaminan Sosial (Lembaran Negara Republik Indonesia Tahun 2011 Nomor 2011 Tambahan Lembaran Negara Republik Indonesia Nomor 116).

Perjanjian Pengalihan Karyawan antara PT Bank CIMB Niaga Tbk., Ronald Hasudungan Sianturi dan PT. Bank Lippo Tbk. 